\title{
ANALISIS PARTISIPASI MASYARAKAT DALAM MEMINIMALISIR DAMPAK PENGGUNAAN MEDIA SOSIAL PADA ANAK MELALUI OMAH BOCAH DI KOANG KECAMATAN JETIS KABUPATEN BANTUL YOGYAKARTA
}

\author{
Ade Sofiana, Sitti Nur Djannah \\ Fakultas Kesehatan Masyarakat, Universitas Ahmad Dahlan
}

*Correspondence: sitti.nurdjannah@ikm.uad.ac.id

Dikirim 30 November 2018; Diterima 2 Desember 2018; Publikasi Februari 2019

\begin{abstract}
Social problems that have occurred have been successfully adopted by the development media that can be used as victims or perpetrators of crime through social media. The many negative impacts of using social media to make children, build the Omah Bocah community in the Koang area of Jetis District, Bantul Regency, Yogyakarta with the aim of minimizing the use of social media. The importance of integrating the community in the context of social issues so that it can be used to analyze the community in minimizing the use of social media use in children through Omah Bocah in Koang, Jetis District, Bantul Regency, Yogyakarta. Qualitative research with observational descriptive design. Using interview and observation methods. The research subjects consisted of eleven people consisting of one of the founders of Omah Bocah, two Omah Bocah administrators, three children of Omah Bocah users, two community leaders and three communities. Data collection tools are interview guides, observation guides, handpones and stationery. Omah Bocah is a community that aims to minimize the impact of using social media. The history and strategy of the establishment of Omah Bocah with the role of community participation has included determining strategic locations and easy access. socialization of the delivery of vision and mission. Community empowerment and community self-reliance according to ability. Participation is seen from participation in planning, implementation, monitoring evaluation and utilization has been running well to include all levels of society with their respective roles. Obstacles from the implementation of Omah Bocah in the form of awareness from their children and also the ability to procure materials by the Omah Bocah management.
\end{abstract}

Keywords: Omah Bocah, Analysis, Participation, Community

\section{PENDAHULUAN}

Partisipasi masyarakat adalah suatu hal yang sangat penting dalam pelaksanaan pemberdayaan masyarakat dalam bidang pembangunan, baik dalam bidang pembangunan kesehatan, pendidikan maupun perekonomian. Didalam partisipasi sangat dibutuhkan adanya Kesadaran, kemauan dan kemampuan hidup masyarakat yang menjadi aspek terpenting dalam tumbuh kembangnya partisipasi. Partisipasi masyarakat adalah keikutsertaan dan kemitraan masyarakat dan fasilitator dalam pengambilan keputusan, perencanaan, pelaksanaan, pemantauan, penilaian kegiatan dan program-program kesehatan serta untuk memperoleh manfaat dari keikut sertaannya dalam rangka membangun kemandirian masyarakat(1). 
Partisipasi masyarakat untuk penanganan suatu permasalahan sosial dalam berbagai hal di masyarakat dapat memberikan kedudukan yang positif dan saling mengisi serta melengkapi tindakan penanganan yang dilakukan oleh pemerintah. Partisipasi masyarakat pada umumnya merupakan tindakan perorangan maupun tindakan bersama yang diharapkan dapat berdampak pada kondisi kehidupan yang lebih baik. Secara umum, masyarakat yang dapat mengelola dan mengatasi masalah sosial memiliki tingkat kesejahteraan yang lebih tinggi dibandingkan dengan masyarakat lain(2).

Salah satu Permasalahan sosial yang tengah terjadi di masyarakat, yaitu dampak dari kemunculan teknologi komunikasi informasi yang terus berkembang di era modren ini. Perkembangan yang sangat pesat terjadi dalam penggunaan media sosial yang tentunya akan membawa dampak, baik dampak positif maupun dampak negatif khususnya di kalangan anak-anak. Penggunaan media sosial pada anak akan cenderung menjadikan anak tersebut menjadi orang asing di dalam lingkungannya sendiri. Media sosial juga dapat mengubah pola hidup, serta mendatangkan kebiasaan-kebiasaan baru bahkan mampu mengubah perilaku dan cara seseorang berkomunikasi dengan orang lain(3).

Menurut Komisi Perlindungan Anak Indonesia (KPAI), kekerasan pada anak selalu mengalami peningkatan setiap tahunnya. Pada tahun 2011 telah terjadi 2.275 kasus kekerasan terhadap anak dengan 887 kasus kekerasan seksual pada anak. Pada tahun 2012 terdapat 3.871 kasus kekerasan pada anak dengan 1.028 kasus kekerasan seksual pada anak. Pada tahun 2013 terdapat 2.637 kasus dengan jumlah kasus kekerasan seksual pada anak sebanyak 1.266 kasus. Kasus kekerasan pada anak terus terjadi pada tahun-tahun berkikutnya dan mengalami peningkatan di tahun 2014 terdapat 5.066 kasus dan pada tahun 2015 ditemukan kasus kekerasan pada anak sebesar 6.006 kasus hingga pada tahun 2016 mengalami kenaikan hingga 1000 kasus dengan 136 kasus kekerasan anak melalui media social(4).

Semakin banyaknya fenomena permasalahan sosial yang diakibatkan oleh perkembangan media sosial yang dapat menjadikan anak sebagai korban maupun pelaku dalam kejahatan melalui media sosial, maka hal tersebut menimbulkan munculnya rasa keperdulian masyarakat terhadap anak anak, sehingga dibangunlah komunitas Omah Bocah di daerah Koang Desa Trimulyo Kecamatan Jetis Kabupaten Bantul Yogyakarta dengan tujuan untuk meminimalisir dampak penggunaan media sosial tersebut. Adapun kegiatan-kegiatan di Omah Bocah yang dapat mendukung berlangsungnya tujuan yang telah di tetapkan yaitu kegiatan yang positif seperti kegiatan belajar dan bermain bersama, kegiatan pengembangan kreatifitas dan bakat anak, kegiatan pengenalan budaya dan penanaman nilai nilai budaya pada anak, dan juga kegiatan keadamaan dan ilmu sosial bermasyarakat.

Berdasarkan hasil wawancara dengan orang tua anak sebagai masyarakat di Koang menilai bahwa penting adanya Omah Bocah di daerah Koang karena dapat membantu para orang tua untuk mendidik anak-anaknya dan dapat menekan atau membatasi anak mereka untuk bermain HP khususnya media sosial sehingga tidak terjadi kemungkinan-kemungkinan munculnya dampat negatif dari penggunaan media sosial tersebut. Sehingga keberadaan Omah Bocah ini diharapkan dapat maju dan juga dilestarikan di daerah Koang ini. Adapun kegiatan-kegiatan di Omah Bocah yang dapat mendukung berlangsungnya tujuan yang telah di tetapkan yaitu kegiatan yang positif seperti kegiatan belajar dan bermain bersama, kegiatan pengembangan kreatifitas dan bakat anak, kegiatan pengenalan budaya dan penanaman nilai nilai budaya pada anak, dan juga kegiatan keadamaan dan ilmu sosial bermasyarakat.

Kegiatan di Omah Bocah dilaksanakan setiap hari libur anak-anak atau tepat setiap hari Minggu pagi. Semua kegiatan ini dikemas dengan penyampaian atau penggunaan metode bermain sehingga anak anak tidak akan mudah bosan saat 
berada di Omah Bocah. Semua kegiatan ini dimaksudkan untuk mengalihkan perhatian anak terhadap keasikan dalam menggunakna media sosial. Didalam Omah Bocah juga diperkenalkan dengan permainan permainan tradisional yang dapat memupuk rasa kebersamaan dan gotong rongong yang menjadi budaya di daerah jawa.

Berdasarkan permasalahan sosial yang ada yaitu dampak penggunaan media sosial dan pentingnya partisipasi masyarakat dalam menyelesaikan permasalahan sosial melalui komunitas Omah Bocah tersebut maka peneliti ingin melihat bagaimana Partisipasi masyarakat untuk meminimalisir dampak negatif penggunaan media sosial pada anak melalui Omah Bocah tersebut.

\section{METODE PENELITIAN}

Jenis penelitian yaitu penelitian kualitatif dengan rancangan deskriptif observasional. Pengumpulan data dilakukan dengan teknik wawancara, observasional dan dokumentasi. Subjek penelitian terdiri dari satu orang pendiri Omah Bocah, dua orang pengurus Omah Bocah, tiga orang anak pengguna Omah Bocah, tiga orang tua sebagai masyarakat dan dua orang tokoh masyarakat. Alat yang digunakan yaitu panduan wawancara, panduan observasi, hp sebagai alat perekam dan juga alat tulis. Analisis data dilakukan dengan cara pengumpulan data mentah, kemudian transkip wawancara, membuat koding dan penyimpulan dalam bentuk narasi dan di interpretasikan dan disesuaikan dengan teori yang telah ada dari peneliti terdahulu.

\section{HASIL DAN PEMBAHASAN}

Omah Bocah merupakan suatu lembaga atau komunitas non formal yang mengayomi anak-anak yang ada di wilayah Koang. Tujuan dari berdirinya Omah Bocah ini adalah untuk menghindarkan anak-anak generasi koang dari dampak negatif penggunaan handpone khususnya media sosial. Omah Bocah memiliki tujuan yang positif, sehingga untuk mencapai tujuan yang positif tersebut tentunya didukung dengan kegiatan kegiatan yang positif di dalamnya.

Sejarah berdirinya Omah Bocah dapat dilihat dari dua hal yaitu pertama dari latar belakang berdiri dan kedua awalmula berdirinya Omah Bocah. Latar belakang berdirinya Omah Bocah yaitu adanya berita di televisi terkait kasus kasus kejahatan atau kriminal yang melibatkan anak-anak. Berita tersebut melibatkan anak-anak sebagai pelaku maupun korban tindak kejahatan yang ada di media sosial. Kemudian semakin banyaknya anak-anak yang sudah menggunakan handpone dan membuka situs-situs orang dewasa. Selain dari kedua hal tersebut, latar belakang berdirinya Omah Bocah juga disebabkan oleh anak-anak yang kurang terarah dalam bermain sehari-hari sehingga tidak mengerti kehidupan bermasyarakat atau tidak membantu orang tua.

Kedua, sejarah dilihat dari awal mula berdirinya yaitu berawal dari keperdulian atau keperihatian salah seorang masyarakat atas keadaan anak-anak yang ada di daerah tersebut. Selanjutnya dari keperdulian tersebut maka ia mengajak masyarakat yang mau bergabung secara sukarela untuk mendirikan suatu komunitas yang menaungi anak-anak di daerah Koang tersebut. Masyarakat yang turut terlibat secara sukarela didalam Omah Bocah yaitu pemuda pemudi yang mau ikut serta menjadi pengurus, orang tua dan juga anak anak. Selain itu awal mula berdirinya juga memnfaatkan lokasi yang telah ada dan berada ditengah tengah masyarakat. Keikutsertaan masyarakat dalam pengelolaan Omah Bocah berdasarkan kesukarelaan tanpa adanya paksaaan. Seperti yang disebutkan Soejijanto bahwa kesukarelaan merupakan keterlibatan seseorang dalam kegiatan 
pemberdayaan yang berlangsung tanpa adabnya paksaan, melainkan harus dilandasi oleh kesadaran sendiri dan motivasinya untuk memperbaiki dan memecahkan masalah kehidupan yang dirasakan(5).

Strategi pendirian Omah Bocah untuk menarik partisipasi masyarakat yaitu seleksi lokasi yang telah sesuai atau strategi karena mudah dijangkau dan menjadi pusat kegiatan masyarakat Koang. Selanjutnya strategi pelaksanaan sosialisasi, sosialisai telah dilaksanakan di Omah Bocah dengan mengundang seluruh lapisan masyarakat. Dalam sosialisasi juga disampaikan visi misi atu tujuan dari pendirian omah bocah. Sosialisai ini bertujuan untuk memberikan pemahaman kepada masyarakat terkait Omah Bocah. Sejalan dengan yang di sebutkan oleh Mardikanto bahwa melalui sosialisasi akan membantu untuk meningkatkan pemahaman masyarakat dan pihak terkait tentang program atau kegiatan yang telah direncanakan(6). menurut septiani bahwa kegiatan sosialisasi bertujuan untuk memberikan gambaran menyeluruh atau utuh tentang tata cara pelaksanaan program 7 . Sehingga diharapkan dengan adanya sosialisasi yang telah dilakukan oleh Omah Bocah maka masyarakat memahami maksud dan tujuan dari pendirian Omah Bocah ini. sehingga dapat membuka dan menarik partisipasi dari masyarakat untuk mau ikutserta membantu didalam kegiatan Omah Bocah dalam upaya meminimalisir dampak negatif penggunaan media sosial pada anak-anak di daerah Koang.

Strategi selanjutnya yang dilakukan Omah Bocah yaitu pemberdayaan masyarakat dan juga pemandirian masyarakat. Pemberdayaan masyarakat dengan melipatkan pemuda atau masyarakat menjadi pengurus Omah Bocah secara sukarela dan juga seluruh lapisan masyarakat sesuai dengan perannya. Pengurus yang ada di Omah Bocah melakukan kegiatan mulai dari perencanaan kegiatan minggan, melakukan pelaksanaan kegiatan hingga pada pelaksanaan monitoring dan evaluasi. Dalam penelitian Nikkhah H.A Anggota komunitas terlibat dalam seluruh proses, mulai dari pengambilan keputusan hingga evaluasi. Komunitas memiliki lebih banyak kekuatan dan kontrol atas keputusan. Karena orang dapat melakukan segalanya untuk meningkatkan kualitas hidup mereka, mereka akan menjadi mandiri dan akan memberdayakan. Perkembangan ini juga akan berkelanjutan karena masyarakat dapat memenuhi kebutuhan mereka di luar bantuan pemerintah(7).

Kemudian dalam pemandirian masyarakat, masyarakat diberi kesempatan untuk ikut berpartisipasi di Omah Bocah sesuai dengan kemampuan yang dimiliki oleh masyarakat tersebut tanpa adanya unsur paksaan, sementara pengurus melakukan pengawasan terhadap pelaksanaan kegiatan. Sejalan dengan yang disebutkan oleh Mardikanto bahwa proses pemberdayaan yang baik yaitu yang mencakup didalamnya kegiatan untuk mengidentifikasi masalah, kemudian melakukan rancangan rancangan dalam menyelesaikan permasalahan yang ditemukan hingga menetapkan rencana yang tepat dan mampu diterapkan dalam suatu kelompok dan pada tahapan akhir berupa adanya proses pemantauan secara terus menerus. pemandirian masyarakat ini bertujuan untuk meningkatkan taraf kehidupan, maka arah pemandirian ini adalah berupa pendampingan untuk menyiapkan masyarakat agar benar benar mampu(8).

Kegiatan di Omah Bocah berlangsung rutin disetiap hari libur sekolah anakanak yaitu hari minggu. Kegiatan setiap hari minggu yang ada di Omah Bocah dilaksanakan mulai pagi hari hingga menjelang siang hari. Kegiatan di Omah Bocah merupakan kegiatan-kegiatan yang positif seperti kegiatan belajar mengajar yaitu belajar bersama jika anak-anak memiliki pejerjaan rumah dari sekolah dan belum mampu untuk mengerjakan sendiri maka dapat belajar bersama di Omah Bocah, kegiatan bermain bersama yaitu dengan bermain hal hal baru bersama dengan anak-anak yang ada di Omah Bocah, pengembangan bakat dan kreatifitas anak serta 
pengenalan budaya dan juga pengajaran dalam keagamaan yaitu dengan memberikan kesempatan kepada anak untuk mengembangkan bakat yang dimiliki seperti dalam berpuisi bermain drama dan bakat serta kreatifitas lainnya, yang nantinya dapat di tampilkan diacara yang diadakan oleh desa. Semua kegiatan yang ada di Omah Bocah ini ditujukan untuk mengalihkan perhatian anak-anak dari penggunaan media sosial yang dapat membawa dampak negatif bagi anak-anak jika penggunaannya diluar pengawasan orang tua.

Semua hal yang telah disebutkan melalui kegiatan kegiatan yang ada di Omah Bocah merupakan hak yang harus diperoleh anak anak yaitu hak untuk berkembang, mencakup hak atas pendidikan, informasi, waktu luang, kegiatan seni dan budaya, kebebasan berfikir, berkeyakinan dan beragama serta hak perlindungan khusus. Hal tersebut menurut Konvensi Hak Anak (KHA) yang di adopsi dari masjelis umum PBB tahun 19894.

Konvensi Hak Anak merupakan sebuah perjanjian hukum international tentang hak-hak anak. Indonesia sendiri meratifikasi Konvensi Hak Anak (KHA) melalui Keppres No.36 tahun 1990 pada tanggal 25 Agustus 1990. Konsekwensi atas telah diratifikasinya Konvensi Hak Anak tersebut, maka Indonesia berkewajiban untuk melaksanakan ketentuan-ketentuan yang terkandung dan atau memiliki kewajiban untuk memenuhi hak-hak anak yang diakui dalam KHA yang secara umum memberikan perlindungan dan penghargaan terhadap anak, agar anak dapat merasakan seluruh hak-haknya, sehingga terjauh dari tindakan kekerasan dan pengabaian(9).

Partisipasi dibagi menjadi dalam empat tahap yaitu pengabilan perencanaan, partisipasi dalam pelaksanaan kagiatan, partisipasi dalam pemantauan dan evaluasi, partisipasi dalam pengambilan manfaat.Tahapan partisipasi masyarakat dalam penyelenggaraan kegiatan-kegiatan sebagai upaya untuk meminimalisir dampak negatif penggunaan media sosial di Omah Bocah Koang yang telak dilakukan yaitu partisipasi perencanaan, partisipasi pelaksanaan, partisipasi monitoring evaluasi dan partisipasi pemanfaatan.

Partisipasi perencanaan yang ada di Omah Bocah meliputi kegiatan rapat atau diskusi untuk penentuan nama selain itu juga untuk menentukan kegiatan mingguan. Partisipasi yang lebih banyak diberikan oleh masyarakat yaitu berupa masukan saran saran kepada Omah Bocah yang dapat dijadikan sebagai bahan pertimbangan dalam melakukan setiap kegiatan-kegiatan yang ada di sana. Partisipasi perencanaan yang meliputi berbagai kegiatan didalamnya seperti pengambilan keputusan, rapat/diskusi, sumbang pemikiran atau ide, saran dan masukan dll. Dalam pengambilan keputusan lebih banyak melibatkan pengurus yang ada di Omah Bocah, namun partisipasi masyarakat dalam pengambilan keputusan juga dilibatkan dengan melalui pemberitahuan atau surat persetujuan didalam sebuah undangan kepada orang tua atau masyarakat. Seperti yang disampaikan oleh Irene $\mathbf{S}$ bahwa partisipasi pada tahap perencanaan ini dapat berupa keikutsertaan atau kehadiran dalam rapat, diskusi, sumbang pemikiran atau ide, tanggapan persetujuan ataupun penolakan pada program program yang di tawarkan(10).

Partisipasi pelaksanaan kegiatan di Omah Bocah diikuti oleh kehadiran dari anak anak sebagai pengguna dari Omah Bocah. Anak-anak di Omah Bocah rajin mengikuti kegiatan di Omah Bocah jika tidak terkendala dengan keadaan sakit dan bepergian. Selain itu keikutsertanya pengurus disetiap kegiatan di Omah Bocah. Pengurus Omah Bocah selalu hadir dalam setiap kegiatan di Omah Bocah, namun keikutsertaan dengan sukarela sehingga jika ada pengurus yang memiliki kesibukan lain seperti jadwal bekerja maka dapat bergantian untuk mengawasi berjalannya kegiatan di Omah Bocah dengan pengurus lainnya yang tidak ada jadwal kerja. Masyarakat dilibatkan dalam kegiatan mingguan jika mau menawarkan diri secara 
sukarela untuk mengisi atau berbagi ilmu dengan anak-anak di Omah Bocah. Keterbatasan partisipasi masyarakat karena kesibukan yang dimilikiki oleh masyarakat yang beranekaragam. Keikutsertaan masyarakat dalam kegiatan Omah Bocah tentunya dengan unsur kesukarelaan tanpa adanya unsur keterpaksaan. Soejijanto bahwa kesukarelaan merupakan keterlibatan seseorang dalam kegiatan pemberdayaan yang berlangsung tanpa adabnya paksaan, melainkan harus dilandasi oleh kesadaran sendiri dan motivasinya untuk memperbaiki dan memecahkan masalah kehidupan yang dirasakan(11).

Partisipasi monitoring dan evaluasi di Omah Bocah telah dilakukan oleh seluruh lapisan masyarakat. Namun tidak secara formal, karena sifat dari keikutsertaan di Omah Bocah ini adalah kesukarelaan. Selanjutnya untuk evaluasi selalu dilakukan setiap usai kegiatan. Monitoring dan evaluasi dilakukan juga oleh masyarakat dan tokoh masyarakat dengan memberikan masukan melalui pengurus seperti contoh masukan yang diberikan yaitu berupa waktu atau jam pelaksanaan kegiatan yang melebihi waktu zuhur, masyarakat memberikan saran jika waktu zuhur sudah mulai berkumandang maka alangkah baiknya untuk kegiatan di Omah Bocah dihentikan dan tidak melebihi batas zuhur atau dilanjutkan setelah zuhur. Setelah adanya masukan dari masyarakat tersebut selanjutnya Omah Bocah menerima dan menerapkan masukan-masukan dari masyarakat yang sifatnya untuk lebih baik di Omah Bocah tersebut. Masukan atau evaluasi yang diberikan kepada Omah Bocah oleh masyarakat banyak disampaikan melalui pengurus yang ada di Omah Bocah. Karena evaluasi sangat dinilai penting dalm suatu kegiatan. Salah satu aspek yang penting dalam pelaksanaan rencana sebagai bagian dari proses perencanaan yang menyeluruh adalah evaluasi(12).

Partisipasi pemanfaatan hasil yang dirasakan oleh masyarakat dengan keberadaan Omah Bocah yaitu perubahan pada pola bermain anak anak. Anak-anak sudah mulai terarah dalam bermain, selain itu mereka juga sudah tidak bergantung pada penggunaan HP. Anak-anak juga sudah berani memperlihatkan bakatnya kepada orang tua atau masyarakat banyak. Hermawan, Y dan Suryono, Y Parameter untuk mengukur tingkat kemajuan suatu program adalah manfaat bagi masyarakat, yang dimaksud dengan manfaat adalah Omah Bocah telah memberikan sumbangan yang berarti bagi peningkatan mutu kehidupan anak-anak masyarakat Koang tersebut(13).

Hambatan yang ada di Omah Bocah yaitu berasal dari kesadaran dari anakanak pengguna Omah Bocah tersebut. Tingkat partisipasi dari anak-anak pengguna Omah Bocah akan menurun jika yang mengisi kegiatan hanya dari pengurus yang biasa ada di Omah Bocah. Namun berbeda jika yang mengisi kegiatan di Omah Bocah berasal dari luar pengurus Omah Bocah seperti mahasiswa dari universitas yang ada di Yogyakarta yang sesekali mau ikut mengisi kegiatan di Omah Bocah, maka antusuas anak anak akan banyak untuk mebikuti kegaitan di Omah Bocah. Selain itu kendala datang dari pengurus yang terkadang kekurangan materi untuk disampaikan kepada anak-anak. Namun keberadaan kendala-kendala tersebut dapat dihadapi dan terselesaikan dengan adanya kerjasama atau keikutsertaan masyarakat dalam membantu mengisi kegiatan di Omah Bocah sesuai dengan kemampuannya. Seperti jika ada masyarakat yang berprofesi sebagai guru terkadang mau menawarkan diri untuk ikut mengajar atau mengisi kegiatan di Omah Bocah, atau terkadang ada masyarakat yang berstatus sebagai mahasiswa juga menawarkan diri untuk membantu mengisi kegiatan di Omah Bocah dengan kegiatan yang ia dapat di bangku kuliahnya, dan ada masyarakat yang memiliki pengetahuan terkait kesehatan juga menawarkan diri untuk mengajarkan kesehatan kepada anak anak seperti tentang pengolahan sampah, kebersihan individu dan lain sebagainya. Usaha lain yang dilakukan oleh pengurus Omah Bocah dalam menyelesaikan atau menangani permasalahan atau kendala yang ada yaitu dengan 
menjalin kerjasama dengan komunitas-komunitas sejenis dan universitas yang ada di Yogyakarta.

\section{KESIMPULAN DAN SARAN}

Berdasarkan hasil penelitian yang telah dilakukan dapat disimpulkan bahwa Omah Bocah adalah komunitas yang menaungi anak-anak yang ada di daerah Koang untuk meminimalisir dampak negatif penggunaan media sosial dengan mengalihkan perhatian anak-anak dari penggunaan handpone khususnya pada penggunaan media sosial kepada kegiatan yang ada di Omah Bocah. Kegiatan kegiatan yang ada di Omah Bocah merupakan kegiatan yang positif, seperti kegiatan belajar bersama, kegiatan bermain bersama, pengembangan bakat dan kreatifitas anak, pengenalan budaya dan pelajaran keagamaan dan lain-lain. Sejarah berdirinya Omah Bocah dapat dilihat dari adanya latar belakang dan juga awal mula berdirinya Omah Bocah. Strategi Omah Bocah untuk partisipasi masyarakat telah sesuai dengan ketentuan atau strategi yang ada dalam partisipasi masyarakat yaitu seleksi lokasi yang sudah tepat dan mudah di jangkau, kemudian sosialisasi yang telah dilakukan kepada masyarakat yang ada di daerah Koang dengan menghadirkan seluruh elemen masyarakat mulai dari pemuda pemudi, tokoh masyarakat, orang tua dari anak-anak dan anak-anak calon pengguna Oma Bocah, sosialisasi dilakukan dengan pemberian visi misi dan pengenalan. pemberdayaan dan pemandirian masyarakat yang telah mencakup seluruh lapisan masyarakat yang ada di Koang. Partisipsi masyarakat di Omah Bocah Juga sudah baik karena mengikutsertakan seluruh lapisan masyarakat mulai dari partisipasi perencanaan, partisipasi pelaksanaan, partisipasi monitoring evaluasi, dan partisipasi pemanfaatan hasil dimana telah dilaksanakan dengan prinsip kesukarelaan tanpa ada unsur keterpaksaan dan sesuai dengan kemampuan masing-masing. Hambatan yang ada berasal dari kesadaran anak pengguna Omah Bocah dan pengurus yang kurang memiliki stok materi yang di ajarkan. Saran yang dapat diberikan kepada Omah Bocah yaitu dengan meningkatkan kualitas pengurus dengan mengadakan atau megikuti pelatihan-pelatihan seperti pelatihan membuat kerajinan, pelatiahn komunikasi yang baik dan pelatihan lainnya yang dapat diajarkan kepada anak-anak pengguna Omah Bocah. Meningkatkan kerja sama dengan universitas yang ada di Yogyakarta dan komunitas sejenis yang ada, melakukan pertemuan rutin dengan orang tua atau masyarakat untuk memantau perkembangan dan perubahan perilaku anak.

\section{REFERENSI}

1. KemenKes RI, 2013, Peraturan Menteri Kesehatan RI Nomor 65 Tahun 2013 Tentang Pedoman Pelaksanaan Dan Pembinaan Pemberdayaan Masyarakat Bidang Kesehatan, Jakarta: Kementerian Kesehatan RI.

2. Aprillia, Theresia, dkk. (2014). Pembangunan Berbasis Masyarakat. Bandung: Alfabeta.

3. Istiyanto, S.B, 2016, Telepon Genggam Dan Perubahan Sosial Studi Kasus Dampak Negatif Media Komunikasi dan Informasi Bagi Anak-Anak di Kelurahan Bobosan Purwokerto Kabupaten Banyumas. Jurnal Komunikasi Ikatan Sarjana Komunikasi Indonesia (2016).1:58-63.

4. Huraerah abu, 2006, Kekerasan Terhadap Anak, Bandung: Penerbit Nuansa

5. Sulaiman, E, S., 2016, Pemberdayaan Masyarakat di Bidang Kesehatan Teori dan Implementasi, Yogyakarta: Gadjah Mada University Press.

6. Mardikanto, T, 2017, Pemberdayaan Masyarakat Dalam Persepktif Kebijakan Publik, Bandung: Penerbit Alfabeta. 
7. Septiany, I, 2012, Partisipasi Masyarakat dalam Implemenrasi Program Nasional Pemberdayaan Masyarakat (PNPM) Mandiri Perkotaan Dengan Penggunaan Model CLEAR Di Kelurahan Kaliabang Tengah Kecamatan Bekasi Utara Kota Bekasi, Skripsi Ilmu Sosial dan Politik Departemen Ilmu Administrasi, Universitas Indonesia,Depok Jakarta.

8. Nikkhah H.A, 2009, Participation as a Medium of Empowerment in Community Development, European Journal of Social Sciences - Volume 11, 2013, page: 391-398). 